DOI https://doi.org/10.30525/978-9934-26-173-2-16

\title{
САМОСТІЙНА РОБОТА СТУДЕНТІВ ЯК СКЛАДОВА ОРГАНІЗАЦІї НАВЧАЛЬНОГО ПРОЦЕСУ
}

\author{
Корнова Н. I. \\ асистент кафедри біології \\ Національний медичний університет імені О. О. Богомольия \\ Кравчук М. Г. \\ кандидат медичних наук, доиент, \\ доиент кафедри біології \\ Наиіональний медичний університет імені О. О. Богомольия \\ Романенко О. В. \\ доктор біологічних наук, професор, завідувач кафедри біології \\ Національний медичний університет імені О. О. Богомольия \\ м. Київ, Украӥна
}

Формування біологічної компетенції у студентів медичних спеціальностей відбувається в ході комплексної навчальної, методичної, виховної роботи. Традиційними формами навчання у вищому медичному навчальному закладі є лекція, практичне заняття та самостійна робота студента.

Існують різні підходи до класифікації самостійної роботи студентів: відповідно до часу і місця проведення (аудиторна та позааудиторна); за обов'язковістю (обов'язкова, бажана та добровільна). За рівнем мотивації виділяють самостійну роботу високого, середнього та низького рівня. Відповідно до творчого потенціалу студента виділяють репродуктивну самостійну роботу, яка переважає на практичних заняттях і включає виконання завдань відповідно до рекомендацій викладача; реконструктивну самостійну роботу, під час виконання якої студенти пишуть тези, реферати; творчу самостійну роботу, що має на меті самостійне отримання знань, виконання досліджень тощо [1].

У Національному медичному університеті імені О.О. Богомольця викладачі кафедри біології під час викладання навчальної дисципліни «Медична біологія» студентам-медикам визначають та методично забезпечують різні види самостійної роботи, зокрема, самостійну роботу студента при підготовці до практичного заняття, самостійну роботу студента під час практичного заняття під керівництвом викладача; самостійну позааудиторну роботу студента. 
Для організації аудиторної та позааудиторної роботи студентів викладачами кафедри біології підготовлені та видані друком українською та англійською мовами навчальні посібники 3 медичної біології $[5,6]$. В них тема кожного практичного заняття чітко структурована і викладена в такій послідовності: актуальність теми, навчальні цілі вивчення теми, хід виконання аудиторної практичної роботи, запитання і тестові завдання з множинним вибором, контрольні тести ситуативного характеру. В кінці кожного розділу містяться узагальнюючі контрольні питання до розділу, що дає можливість студентам зорієнтуватися в обсязі навчального матеріалу при підготовці до підсумкового контролю рівня їхніх знань та вмінь. Готуючись до практичного заняття, студенти ознайомлюються 3 навчальною метою практичного заняття, опрацьовують теоретичний матеріал, складають конспект відповідно до теми, що вивчається. 3 метою самоперевірки засвоєних знань студенти записують у робочому зошиті відповіді на контрольні запитання та тестові завдання. Такий підхід до засвоєння навчального матеріалу під час вивчення навчальної дисципліни «Медична біологія» є дієвим. Під час виконання практичної аудиторної роботи студенти виконують завдання під керівництвом викладача. Цінність практичного заняття полягає в тому, що студенти застосовують набуті попередньо теоретичні знання на практиці, розуміють та усвідомлюють опрацьований матеріал, що закладає підгрунтя для формування в них клінічного мислення [4]. Самостійна позааудиторна робота студентів передбачає самостійне опрацювання тих тем, які не входять до тематичного плану аудиторних занять. Тому викладачами кафедри біології розроблено рекомендації до позааудиторної самостійної роботи студентів.

Особливої допомоги в оволодінні навичками самостійної роботи потребують студенти першого курсу. Добре організована і методично забезпечена самостійна робота студентів (аудиторна та позааудиторна) відповідає принципам професійної спрямованості, науковості, наочності, систематичності, цілеспрямованості, доступності, наступності, індивідуального підходу, принципу єдності вимог, свідомості, активності та самостійності студентів $[2,3]$. При цьому викладач ознайомлює студентів 3 планом, обсягом, можливостями самостійної роботи, мотивує студентів, періодично контролює результати їх діяльності, забезпечуючи систематичність навчання студентів, вчасне виявлення недоліків та їх усунення, перевіряє рівень засвоєння знань, вмінь та практичних навичок студентів. Тестові завдання, відповіді на контрольні запитання, розв'язування ситуаційних задач належать до категорії засобів оцінювання самостійної роботи студента. 
Систематична самостійна робота під час навчання студентів-медиків забезпечує формування у майбутніх фахівців як фундаментальних знань, які застосовуватимуться на практиці, так і таких особистісних якостей як самостійність, організованість, відповідальність, здатність до аналізу, вміння приймати нестандартні рішення. Отже, самостійна робота $\epsilon$ однією з важливих форм навчально-виховного процесу і невід'ємною його частиною, сприяє реалізації його освітньої, розвивальної та виховної мети.

\section{Література:}

1. Фіцула М.М. Педагогіка вищої школи: навчальний посібник. Київ: «Академвидав», 2006. $352 \mathrm{c.}$

2. Калашнікова Л.М., Жерновникова О.А. Педагогіка вищої школи у схемах і таблицях: навчальний посібник. Харків, 2016. 260 с.

3. Гладуш В.А., Лисенко Г.І. Педагогіка вищої школи: теорія, практика, історія. Навчальний посібник. Дніпропетровськ, 2014. 416 с.

4. Kravchuk M.G., Starostenko O.V., Dymar N.M., Romanenko O.V. Medical biology in professional training of students of medicine: role of independent work. Nowoczesna edukacja: filozofia, innowacja, doswiadczenie. Nr 1 (5). Lodz: Wydawnictwo Naukowe Wyzszej Szkoly Informatyki i Umiejetnosci, 2016. S. 106-110.

5. Романенко О.В., Кравчук М.Г., Грінкевич В.М., Костильов О.В. Медична біологія: Посібник 3 практичних занять / за ред. О.В. Романенка. 2-е вид. Київ «Медицина», 2020. 472 с.

6. Romanenko O.V., Golovchenko O.V., Kravchuk M.G., Grinkevych V.M.; Medical biology: The study guide of the practical classes course / Edited by O.V. Romanenko. Kyiv: Medicine, 2008. 304 p. 